Relations industrielles

Industrial Relations

\title{
Labour Courts in Québec
}

\section{Paul F. Renault}

Volume 17, numéro 1, janvier 1962

URI : https://id.erudit.org/iderudit/1021659ar

DOI : https://doi.org/10.7202/1021659ar

Aller au sommaire du numéro

\section{Éditeur(s)}

Département des relations industrielles de l’Université Laval

\section{ISSN}

0034-379X (imprimé)

1703-8138 (numérique)

Découvrir la revue

\section{Citer ce document}

Renault, P. F. (1962). Labour Courts in Québec. Relations industrielles / Industrial Relations, 17(1), 80-84. https://doi.org/10.7202/1021659ar
Résumé de l'article

Excerpt of an address presented at the 43rd Annual Convention, Canadian Bar Association, Winnipeg, August 28 to Septembre 2, 1961.
Tous droits réservés @ Département des relations industrielles de l’Université Laval, 1962
Ce document est protégé par la loi sur le droit d'auteur. L’utilisation des services d'Érudit (y compris la reproduction) est assujettie à sa politique d'utilisation que vous pouvez consulter en ligne.

https://apropos.erudit.org/fr/usagers/politique-dutilisation/ 


\section{INFORMATIONS}

\section{Labour Courts in Québec *}

Paul F. Renault, Q.c.

Public statements made by officials of the Government of the Province of Quebec with regard to the creation of labour courts, papers presented to the sixteenth Industrial Relations Convention of Laval University on the subject of labour courts, talks given by prominent union executives and well-known members of employers' associations expressing the belief that the establishment of labour courts would bring about a marked improvement in labour relations in the Province of Quebec have undoubtedly led the President of our Labor Relations Section to ask me to speak on the question of labour courts and the latest amendments to the Quebec Labour Relations Act.

Despite the recent interest about labour courts in the Province of Quebec, the Quebec Legislature has not seen fit to raise the question during the last session. In fact, the latest amendments to the Labour Relations Act have not dealt with labour courts at all.

The need to establish labour courts possibly results from the impossibility of our civil courts to deal readily and promptly with matters arising out of labour relations. Unfortunately this has also been the case in all other important matters. The rolls of our courts are crowded and, in almost all of our judicial districts, long delays occur before cases come up for hearing.

The appointment of a Royal Commission to study the administration of justice and the organization of our courts, such as the recently appointed Royal Commission to study matters of education, which could work in co-operation with the already existing Commission studying possible improvements to our Code of civil procedure, and the early implementation of its recommendations, is perhaps the first constructive step which might be taken in order to streamline our judicial system. In the meantime, those who are dissatisfied with the inability of our courts to meet their needs, whether union or management, have begun to discuss and, in some instances, even request special privileges for the group they represent, as has been the case in the creation of the whole of our labour laws during the past twenty-five years; they are now requesting the creation of labour courts in the hope that it will bring about the remedy for their problems.

So far, it has been impossible to establish what is actually meant by the creation of these proposed labour courts and what form they should take. Speaking of the establishment of labour courts, no one has yet suggested what the nature of these courts should be. Are the proposed labour courts intended to take

\footnotetext{
* Excerpt of an address presented at the 43rd Annual Convention, Canadian Bar
} Association, Winnipeg, August 28 to Septembre 2, 1961. 
cognizance of all matters dealing with union or management? If that be the case, who will define what constitutes a labour matter? Should not then the proposed labour courts sit in many cases as the highest tribunal of first instance? Furthermore, how would the proposed labour courts be composed? Would they be composed of judges appointed for life and chosen amongst the members of the Bar? Would they be made up of a judge sitting alone, or of a judge with two assessors or of a president with two arbitrators? Would they in effect be similar to our conciliation or arbitration boards? Do union executives and industrial relations experts wish the proposed labour courts to be composed of judges chosen outside the members of the Bar or people having obtained a law degree? Are not the proponents of labour courts requesting indirectly that the judges be chosen amongst economists, labour or management consultants and social workers? Those are only a few examples of the type of questions which all members of the Canadian Bar Association should consider in order to ensure that they are not lending their support, directly or indirectly, to a movement which could eventually be most detrimental to the administration of justice and to our profession?

A sensible and constructive course of action to be followed at this time would perhaps be the creation of a subdivision of our Superior Court and the appointment thereto of judges who are specially appointed to hear cases dealing with labour matters, including grievances made by employees. The hearing of bankruptcy matters by a special division of the Superior Court has proved rather successful and expedient. This course of action has long been advocated by Me Marie-Louis Beaulieu, Q.C., author and professor of law at Laval University, and more recently by Me Marc Lapointe, professor of law at McGill University. While advocating the establishment of some sort of labour court, these two distinguished lawyers especially have in mind the appointment of more judges who could hear matters arising from the relations between an employer, a union or an employee, and to whom a hearing of these cases could be referred. Of course, it is to be hoped that the additional appointees to the Bench would be chosen amongst lawyers having had experience in labour matters. All labour matters, or matters which in the opinion of the Chief Justice of the Province could be considered a labour case, could be referred to this newly created division of our Superior Court. This, of course, is the more conservative attitude and possibly the only possible course of action to be followed in view of the British North America Act.

The constitutional problem related to the creation of labour courts applies not only to Quebec, but to all provinces, with the addition that in Quebec under section 98 of the British North America Act, \& The judges of the Courts of Quebec shall be selected from the Bar of that Province $\gg$.

Section 96 of the British North America Act provides that \& the GovernorGeneral shall appoint the Judges of the Superior, District and County Courts \$. The provincial legislature has the exclusive power to make laws regarding (a) $<$ the Establishment and Tenure of Provincial Offices, and the Appointment and Payment of Provincial Offices », see section 92 (4), (b) « Property and Civil Rights in the Province s, see section 92 (13), and (c) \& the Administration of Justice in the Province including the Constitution, Maintenance and Organization of Provincial Courts \$, see section 92 (14). From these various sections of the British North America Act it can be seen that section 96 removes from the Provinces and traris- 
fers to the Federal Government th power of appointing the judges of the higher provincial courts.

The principles that have been evolved by the courts in interpreting these various sections of the British North America Act will be reviewed hereafter as well as the leading cases from which these principles have evolved.

In the 1932 case of O. Martineau \& Sons, Ltd. v. Monreal City, (1932) A.C. 113, it was decided that the Quebec Public Service Commission when assessing compensation in expropriation cases is not acting as a Judge of a Superior, District or County Court so as to require that the appointment of its members be made by the Governor-General of Canada.

In the Privy Council decision, and this is really what makes the decision significant and important, their Lordships cite with approval a passage from a British Columbia case in 1890 - Burk v. Tunstall, (1890) 2 B.C.R. 12 - where it was held by Drake J.:

< It is true that the language used in that section is limited to the judges of the superior, district and county Courts in each Province and it might be contended that these courts having been expressly named, all other Courts were excluded. If this were so the provincial legislature would only have to constitute a Court by a special name to enable them to avoid this clause. But in the section itself, after the special courts thus named, the Courts of probate in Nova Scotia and New Brunswick are excepted from the operation of the clause, thus showing that s. 96 was intended to be general in this operation. ?

In the words of Duff, C.J., this passage became:

\& Authority for the proposition that it is incompetent to the provincial legislatures to legislate for the appointment of any officer of any provincial court exercising other than ministerial functions and for the proposition that s. 96 is general in its character in the sense that all provincial courts come within its scope, including courts of summary jurisdiction such as justices of the peace, and that, as regards all such courts exercising, at all events, civil jurisdiction, the appointment of judges and officers presiding over them is vested exclusively in the Dominion. 8

(Duff, C.J., Reference Re Adoption Act. (1938) 3 D.L.R. 497 ).

The case of Attorney-Generay for Quebec v. Slanec and Grimstead, (1933) 3 D.L.R. 289, revolved around the question of whether or not the Quebec Workmen's Compensation Commission was a Court within the meaning of s. 96. The Quebec Appeal Court took a historical view on the question. Two judges decided that the Commission was not a court as meant in section 96 and that it was rather an administrative tribunal. There was no need therefore to decide whether it was a court under section 96. Judge Letourneau decided that, even if the function was judicial, the Commission is not a court under section 96. Judge Rivard dissented on the ground that it was a court under section 96. Although the history of the creation of the board was exhaustively examined, the judges rested their decisions ultimately on the nature of the work done by the board. 
In the case of City of Toronto v. York Township, (1937) 1 D.L.R. 175, the question for consideration before the Privy Council was wether or not the Municipal Board of Ontario was a Superior Court or a tribunal analogous thereto. In following a well settled line of jurisprudence Rowell, C.J.O., came to the conclusion that the powers conferred on the board were judicial rather than administrative and it was therefore \&ultra vires 》 the legislature of Ontario. This decision of the Ontario Court was subsequently upheld by the Privy Council (1938) 1 D.L.R. 593. The latter judgement is unsatisfactory since references to the problem of judicial functions are vague.

The Privy Council did say however that the Ontario Municipal Board was s not validly constituted to receive judicial authority $»$. This statement is held by one commentator, John Willis, 1940 Canadian Bar Review 517, to be the result of a statement of Rowell C.J.O., in the lower court. The latter judge stated that ? The Province is not competent to confer upon a tribunal, created and appointed by it, power to determine purely judicial questions such as are normally determined by courts of Justice ». According to Willis the Privy Council did not make it clear that, by «courts of Justice», the Ontario Court Judge meant Superior Courts. Our courts undoubtedly regarded section 96 as a substantial restriction upon the power of a province to reorganize its judicial machinery, because no functions exercised by any of the courts within section 96 in 1867 can constitutionally be transferred to magistrates or administrative boards. In 1938, however, the Supreme Court of Canada threw doubt upon the fundamental proposition that to increase the powers of a magistrate is to « appoint 》 him with respect to these functions.

In 1938 a case was referred to the Supreme Court of Canada. (Reference Re Adoption Act, 1938 S.C.R. 398). The purpose of the reference was to determine whether County or District Court, etc. Judges (i.e. inferior court judges) had authority to perform the functions vested in them by four provincial statutes. In concluding that these four statutes were «intra vires » the provincial legislature, the Chief Justice of the Supreme Court re-interpreted virtually all preceding decisions on the interpretation of section 96 and other related sections of the B.N.A. Act.

One of the questions discussed in this particular case was whether or not the Provinces have power to pass legislation increasing the jurisdiction of courts of summary jurisdiction beyond that which was theirs at the date of Confederation. The conclusions reached on this question were that a provincial legislature may validly increase the jurisdiction of an inferior tribunal which was in existence at the time of Confederation to any extent and in any direction it pleases so long as it does not either:
A) alter its caracter so as to transform it into one of the courts within section 96 or
B) confer upon it the same kind of functions over the same kind of subject matter as was reserved to courts within section 96 at Confederation - the latter is a question of legal history.

In the 1949 case, Labour Relations Board of Sask. v. John East Iron Works Ltd., 1949 A.C. 134, the Privy Council attempted to clarify any of the confusion that had resulted from the Toronto v. York Township case. It was clearly stated 
in the John East Iron Works Ltd. case that a provincial tribunal can have judicial functions and still not be analogous to a Superior Court. Two questions are to be asked, therefore, when considering section 96 -

(a) does the board or tribunal exercise judicial power?

(b) if so, in that exercise, is it a tribunal analogous to a court under section 96 ?

A recent case on the subject, A.E. Dupont v. Inglis 1958 S.C.R. 535, posed the question of the constitutional validity of a tribunal established, under the Mining Act, R.S.O. 1950, c. 236. The grounds of attack were that the tribunal is or was attempting to exercise the jurisdiction of a Court within the meaning of section 96 of the British North America Act. The interpretation of section 96 as found in Reference Re Adoption Act, Martineau and Sons v. Montreal, and Labor Relations Board of Sack v. John East Ironworks was upheld. Rand J. decided that:

< The province, under its authority over the administration of justice excluding the establishment of Courts, may and is in duty bound to maintain judicial tribunals and define their jurisdiction. The restriction of section 96, with sections 99 and 100 , provisions vital to the judicature of Canada, is confined to courts endowed with jurisdiction conforming broadly to the type of that exercised in 1867 by the courts mentioned in the section or tribunals analogous to them. A distinction is here necessary between the character of a tribunal and the type of judicial power if any exercised by it. If in essence an administrative organ is created, as in Toronto v. York Township there may be a question whether provincial legislation has purported to conver upon it judicial power belonging exclusively to courts within section 96 . Judicial power, not of that type, such as that exercised by inferior courts, can be conferred on a Provincial tribunal whatever its primary character... »

We may conclude from the foregoing decisions that the following principles have been established by our Courts:

1. The provinces have exclusive rights regarding the administration of Justice, including the constitution, maintenance and organization of provincial Courts.

2. The provinces cannot attribute to inferior courts powers which belong to the Superior, District and County Courts.

3. The Federal Government has the exclusive right to appoint judges to the Superior Court.

4. In the Province of Quebec only members of the Bar can be appointed to the Bench.

In view of the above conclusions, it is clear that labour courts dealing with all labour matters cannot be created without amending the British North America Act. 